\title{
FORRÁS
}

FRAZER-IMREGH MONIKA

\section{POLIZIANO ÓDÁJA GENTILE BECCHIHEZ GIULIANO DE' MEDICI HALÁLÁRA}

Az alábbi, horatiusi ihletésű ódát Angelo Poliziano 1478 decemberének végén írta a Medici fivérek egykori nevelője és tanára, Gentile Becchi számára, aki 1473-tól Arezzo püspökeként szolgált. ${ }^{1}$ A vers a gyászában elmerült tudós püspöknek igyekszik lelki vigaszt nyújtani, miután a Pazzi-összeesküvésben az akkor huszonhárom esztendős Giulianót 1487. április 26-án, a szentmise alatt a firenzei dómban Francesco Pazzi és Bernardo Baroncelli tizenkilenc tőrdöféssel megölte. Az eseményekről és azok résztvevőiről Poliziano latin nyelvű visszaemlékezésében számolt be, ez a Commentarium Pactianae coniurationis. ${ }^{2}$ Poliziano azonban nem beszél az összeesküvés Firenzén kívüli politikai hátteréről, és annak pápai jóváhagyásáról IV. Sixtus részéről. Az utóbbit a gyilkosság után őrjöngve igazságért kiáltó Gentile Becchi tárta fel, aki Firenze és Lorenzo pápai kiátkozása után püspökként egy „ellenkiátkozást” hirdetett meg, s a pápát Krisztus elárulójának, az egyház megrontójának, sőt egyenesen „az ördög vikáriusának” nevezte, messze megelőzve a reformátorokat a pápák hatalmi szerepének megkérdőjelezésében. Érveit a Florentina synodus című müvében fogalmazta meg, amelyben részletesen leírja a kialakult feszült politikai helyzet előzményeit, az ördögi terv(ek) előkészületeit. ${ }^{3}$ A kihallgatások nyomán a fennmaradt dokumentumok egyébként még a pápa és az összeesküvők között zajlott megbeszéléseket is felidézik. ${ }^{4}$ Több terv is született a két Medici fivér, Lorenzo és Giuliano tőrbe csalására, melyek közül az első néhányat egyéb okok miatt nem sikerült az összeesküvőknek kivitelezniük.

Poliziano 1478 második felét a feszültségek és a frissen kitört pestis miatt Gentile Becchivel együtt Pistoiában és Cafaggiolóban töltötte Lorenzo gyermekeivel azok nevelőiként. ${ }^{5}$ A közösen viselt gyász enyhítésére született meg tehát a szóban forgó költe-

1 A Polizianóról szóló terjedelmes szakirodalomból lásd M. Martelli: Angelo Poliziano. Storia e metastoria. Lecce (1995). Becchiről lásd N. Marcelli: Gentile Becchi (1430-1497) precettore di casa Medici. Un caso atipico del secondo Quattrocento? Annali di Storia dell' Educazione e delle Istituzioni scolastiche XX (2013) 27-40. Bővebben: N. Marcelli: Gentile Becchi. Il poeta, il vescovo, l’ uomo. Firenze (2015).

2 A. Poliziano - G. Becchi: La congiura della verità. Introd., comm. e cura di M. Simonetta, trad. di G. Fortunato. Testo latino a fronte. Napoli (2012) 56-84.

${ }^{3}$ Uo. $90-168$.

${ }^{4}$ Levelek a következőktől: Giuliano della Rovere, Filippo Sacramoro (a Sforzák követe Firenzében), Gian Francesco Mauruzzi és Gian Battista Montesecco zsoldosvezér vallomása, akit Lorenzo meggyilkolására fel akartak bérelni, de miután megismerkedett vele, elállt a megbízástól. Uo. 171-192.

${ }^{5}$ E. Curti: Introduzione. In: A. Poliziano: Lettere volgari. Roma (2016) XV; és uo. 11-22. levél, $24-42$. 
mény. 1479-ben az akkor négyesztendős Giovanni latinoktatását is Polizianóra bízzák, Lorenzo felesége, a római származású Clarice Orsini azonban bigottabb szemlélete miatt összetűzésbe került Polizianóval annak humanista tantervű oktatási módszertanát nehezményezve. (Többek között Vergilius és Catullus is szerepelt a tananyagban, Clarice viszont csak a zsoltárokat olvastatta volna a fiaival.) Clarice tehát 1479 áprilisában elküldte a háztól Polizianót, ${ }^{6}$ aki július végén Velence, Padova és Verona felé vette az irányt, majd Mantovában tartózkodott egy ideig, ahol Francesco Gonzaga vendégeként, annak kérésére néhány nap alatt vetette papírra a Fabula di Orfeót, amely később az első opera, Monteverdi művének a szövegkönyve lett (némi módosításokkal). ${ }^{7}$

Velencében Poliziano találkozott Ermolao Barbaróval és Girolamo Donatóval, akiknek felolvasta ezt az ódáját - e tényt Donato meg is említi Polizianóhoz 1485. június 8-án írt levelében. ${ }^{8}$ Nagy hatással volt rá a költemény szépsége és stílusa, mint írja: „Azóta valahányszor csak a művelt főkről esett szó, mindig te jutottál eszembe legelőször mindjük közül." ${ }^{9}$ A címben szereplő jelző: dicolos, arra utal, hogy kis asklépiadési és glykóni sorokból áll, tehát kis asklépiadési versszakokból épül föl, csakúgy, mint például Hor. Carm. I, 6 (Agrippához):

$$
\begin{gathered}
---v v-/-v v-v- \\
---v v-/-v v-v- \\
---v v-/-v v-v- \\
---v v-v-
\end{gathered}
$$

E párhuzamot Peter E. Knox ajánlja, aki Poliziano görög és latin nyelvű verseit angol prózafordítással adta ki, ${ }^{10}$ véleményem szerint azonban Hor. Carm. I, 24 (Vergiliushoz) megfelelőbb párhuzam lenne, hiszen ez is egy vigasztaló óda, méghozzá a Maecenas-körhöz tartozó irodalomkritikus, Quintilius Varus, közös jóbarátjuk halálakor.

A verset Poliziano levele vezeti be, amelyet Lorenzo de' Medicinek írt, arra vágyva, hogy patrónusa hívja vissza Firenzébe. Lorenzo 1479-ben a Firenze ellen alakuló szövetségeket megakadályozandó Nápolyba hajózott Aragóniai Ferrante királyhoz. Poliziano több, Lucrezia Tornabuonihoz, Lorenzo édesanyjához és magához Lorenzóhoz

${ }^{6}$ Clarice ekkor az erődszerű családi nyaralóban, Cafaggiolóban tartózkodott a gyermekekkel, Poliziano innen a Firenzéhez közeli Careggibe, majd Fiesoléba ment. Lásd Poliziano: i. m. (5. j.) 24-27. levél, 50-56.

7 A. Poliziano: Stanzák; Orfeusz története. - Stanze; Fabula di Orfeo. Ford. Simon Gy. Budapest (2003) 98-123.

${ }^{8}$ A. Poliziano: Letters. Vol. I, Books I-IV. Ed., transl. Sh. Butler. Cambridge Massachusetts - London (2006) 122.

${ }_{9}$ Uo.

10 A. Poliziano: Greek and Latin Poetry. Ed. and transl. P. E. Knox. The I Tatti Renaissance Library 86. Cambridge Massachusetts - London (2018) 347, 147. j. 
írt kérelmező levele ${ }^{11}$ után a diplomáciai útjáról visszaérkező Medici végül is visszahívta őt Firenzébe, és kinevezte a Firenzei Egyetem görög és latin filológia oktatójává. Így 1480-tól kezdte meg professzori pályafutását, amihez számos szemléltető jellegü tankölteménye, például a Sylvae négy könyve is kapcsolódik. A Manto (1482) Vergilius és Theokritos stílusában mutatja be bukolikus költészetüket, a Rusticusban (1483) Hésiodos Munkák és napok és Vergilius Georgicon című műveit szemlélteti, az Ambra (1485) a homérosi eposzokat imitálja, a Nutricia (1486) pedig egyfajta verses irodalomtörténeti áttekintése az antikvitásnak, kitekintéssel Dante, Petrarca és Cavalcanti költészetére, amelyet Lorenzo dicséretével zár.

Gentile Becchi egyébként továbbra is Lorenzo fiainak nevelője maradt. 1480-ban Piero oktatását Arezzóban folytatja, amiről Ficino egyik levele is tanúskodik:

Dici non posset quantum probem Laurentium Medicem Petrum primogenitum suum Gentilis magistri quondam sui disciplinae dedicavisse. Spero enim puerum istum educatione eiusmodi, senem brevi vel in ipsa pueritia evasurum. Quo nihil antiquius, nihil magis necessarium Plato noster esse illis existimat, qui reipublicae gubernacula sunt feliciter accepturi. ${ }^{12}$

1488-ban Lorenzo leányát, Maddalenát az édesanyával, Claricével együtt Gentile kíséri el Rómába, hogy férjhez adják Francesco Cibóhoz, 1492-ben pedig a már korábban bíborossá választott Giovannit kíséri szintén Rómába. ${ }^{13}$

\section{XCVI}

Angelus Politianus Laurentio Medici patrono suo salutem ${ }^{14}$

Qua ode Gentilem nostrum nuper sum consolatus, eandem quoque ad te mittendam statui. Visa est enim res, quae non minus ad te quam ad eum atque ad me ipsum pertineret. Omnia collegi, quae communem hunc nostrum dolorem, etsi minus tollere, levare procul dubio aliqua ex parte possint. Tu cum tot videas tuae saluti tam diligenter invigilare, potes admoneri quam tibi necesse sit magni te ipsum facere, neque tuam, hoc est publicam totius (ita me Deus amet) Italiae salutem, neglectam pati. Lege et vale.

11 Poliziano: i. m. (5. j.) 24-27. levél, 50-56; és Poliziano 1479. április 16-án kelt latin nyelvű levele Lorenzóhoz: Firenzei Állami Levéltár, Mediceo avanti il Principato, XXXVII, 227; G. B. Picotti: Tra il poeta e il lauro. Pagine della vita di Agnolo Poliziano. In: Ricerche umanistiche. Firenze (1955) 71, III. dokumentum.

12 Ficini Opera I. 833-834.

13 Poliziano: i.m. (5. j.) 44.

14 XCVI. „Ad Gentilem episcopum ode dicolos”. In: Poliziano: i. m. (10. j.) 112-114. 
Ad Gentilem episcopum ode dicolos

Gentiles, animi maxima pars mei,

Communi nimium sorte quid angeris?

Quid curis animum lugubribus teris,

Et me discrucias simul?

$5 \quad$ Passi digna quidem perpetuo sumus

Lucru, qui mediis, heu miseri, sacris

Illum, illum iuvenem vidimus, o nefas,

Stratum sacrilega manu.

At sunt attonito quae dare pectori

10 Solamen valeant plurima: nam super

Est qui vel gremio creverit in tuo

Laurens, Etruriae caput.

Laurens, quem patriae caelicolum pater

Tutum terrifica Gorgone praestitit;

15 Quem Tuscus, pariter quem Venetus leo

Servant et draco pervigil.

Illi bellipotens excubat Hercules;

Illi fatiferis militat arcubus;

Illi mittit equos Francia Martios,

Felix Francia regibus.

Circumstat populus murmure dissono,

Circumstant iuvenem purpurei patres.

Causa vincimus et robore militum:

Hac stat Iuppiter, hac favet.

25 Quare, ocum misera quid tibi nenia,

Si nil proficimus? Quin potius gravis

Abstersisse bono laetitiae die

Audes nubila pectoris?

Nam cum iam gelidos umbra reliquerit

30 Artus, non dolor hanc perpetuus retro

Mordacesve trahunt sollicitudines

Mentis curaque pervicax. 
96.

Angelo Poliziano patrónusának, Lorenzo de’ Medicinek

Úgy határoztam, számodra is elküldöm azt az ódát, amellyel Gentile barátunkat vigasztaltam a minap. Úgy tűnt ugyanis, hogy témája legalább annyira tartozik rád és rám, mint őrá. Összeszedtem mindent, ami még ha közös gyászunkat feledtetni nem is tudja, kétségkívül valamennyit enyhíthet rajta. Te, midőn látod, hányan ügyelnek nagy figyelemmel épségedre, ez intő jel lehet számodra, hogy milyen fontos kellő figyelmet fordítanod saját magadra, és hogy ne hagyd, hogy épséged, vagyis (bizony Isten) egész Itália közös épsége felügyelet nélkül maradjon. Olvasd hát, és élj boldogul!

\section{Kettős metrumú óda Gentilének, a püspöknek}

Gentilém, teveled lelkem is egybeforrt,

Mért aggódsz? Közösen sújt ez a gyász reánk...

Lelked szívszoritó gondjai így minek

Kínoznak? Beleőrülök...

5 Mit türtünk, az örök gyászt követel, hiszen

Láttuk mint kaszabolt - jaj minekünk! - fiút,

Ó ég, azt a fiút vérbe fagyasztva, jaj,

Bünös kéz - de a szentmisén!

Mégis sok lehet ím, vígasza bánatunk

10 Terhének, mi gyötör, hisz mivelünk maradt

Testvérbátyja, Lorenz', véle nevelted őt,

Toszkán föld feje, híres úr!

Győzelmes, kit az ég, istenek atyja véd

Gorgó, rettenetes átkaitól, kire

15 Toszkán és a venét mind ugyanúgy ügyel,

Örzik nagyvadaik hüen. ${ }^{15}$

Örá háboruban nagyszerü Herkules

Őrköd, és nyilait messzire szórja el,

Néki francia küld hadsereget, lovat,

Boldog, mert a királya jó.

${ }^{15}$ Utalás Szent Márk, s egyben Velence és Firenze szimbolikus állatára, az oroszlánra és a Milánói Hercegség címerében szereplő kígyóra. 
Köznép körbeveszi, s lám nagy a zaj, lesik, Ifjú bár, körüláll agg vezetők raja.

Nyernünk kell igazunk és seregünk miatt:

Így lesz, Juppiter így segít.

25 Mért gyászolsz? Ha siratsz, semmire nem megyünk...

Mért nem jössz, szivedet fellegek árnyitól

Tisztítsd már e vidám, napsugaras napon,

Nyisd meg hát ma a lelkedet!

Hisz hűlő tagodat hogyha a lelked ím

30

Elhagyta, s kialudt benned a fény, a gond

Nem hoz vissza, makacs aggodalom se bú,

Nem támaszt fel a fájdalom.

FRAZER-IMREGH MONIKA

Károli Gáspár Református Egyetem BTK Ókortörténeti és Segédtudományi Tanszék

imreghmonika@gmail.com

Open Access. A cikk a Creative Commons Attribution 4.0 International License (https://creativecommons.org/licenses/by/4.0) feltételei szerint publikált Open Access közlemény, melynek szellemében a cikk bármilyen médiumban szabadon felhasználható, megosztható és újraközölhető, feltéve, hogy az eredeti szerző és a közlés helye, illetve a CC License linkje és az esetlegesen végrehajtott módosítások feltüntetésre kerülnek. (SID_1) 